\title{
ICDS and supplementary nutrition programme to children in rural areas of Kasargod, Kerala
}

\author{
N. Karunakaran \\ Principal and Research Guide in Economics of Kannur University, Dept. of Economics, People Institute of Management Studies, \\ Kasaragod, Kerala, India
}

*Corresponding Author: N. Karunakaran

Email: narankarun@gmail.com

\begin{abstract}
Integrated Child development Service (ICDS) is a national programme for the promotion of mother and child health. The beneficiary includes children below 6 years, pregnant and lactating mothers, and other woman in the age group of 15 to 44 years. The package of services includes supplementary nutrition, immunization, health checkup, referral services, nutrition, health and pre-school education and is mainly implemented through 'Anganwadi'. There is a massive improvement in the nutritional status of children living in rural and tribal areas belonging to different sections of the community due to the implementation of the Supplementary Nutrition Programme (SNP).
\end{abstract}

Keywords: Anganwadi, Supplementary nutrition programme, Rural area, Kasaragod.

\section{Introduction}

ICDS scheme was launched in 1975. Tenth five year plan linked ICDS to Anganwadi centre established mainly in rural areas. A typical Anganwadi centre provides basic health care in villages. One of the important services of Anganwadi centre including Supplementary Nutrition Programme (SNP) and is one of the six services provided under the ICDS scheme; which is primary designed to bridge the gap between the recommended dietary allowance (RDA) and the average daily intake (ADI). Supplementary nutrition is given to the children ( 0 to 6 year) and pregnant and lactating mothers under ICDS scheme. Present paper analyzed the Supplementary Nutrition Programme for children through Anganwadi in the rural areas of Kasaragod district in Kerala.

\section{Methods and Materials}

Kristine Peterson (2009), Michele Gragnolati, et. al. (2006), Mushtaq Pasha, et. al. (2017), Nair K R G (2007), Nandini Nayak and Naresh C Saxeena (2006), Samir Garg (2006), Santhosh Mehrotra (2006), Karunakaran N (2016), and Shanti Ghosh (2004) studied ICDS, the impact of nutritional supplement intakes, nutritional status of Anganvadi children and so on in the different parts of India. Sources of data for the study consist both primary and secondary. Primary data were collected from the rural areas of Parappa block Panchayat of Kasaragod and secondary data from various published and unpublished documents. Primary data were randomly collected from the 24 Anganwadi in the six Panchayat of Parappa block.

\section{Results and Discussion}

ICDS scheme is the largest, programmes for the promotion of maternal and child health and nutrition in India was launched in 1975 in pursuance of the National policy for children. It is a multi-sectoral programme and involves several government departments and is coordinated at the village, block, district, state and central government level. The primary responsibility for the implementation of the programme lies with the Department of Women and Child
Development at the centre and nodal departments at the states like social welfare, Rural Development, Tribal Welfare or Health Department or an independent department. It is one of the largest early child care programmes for improving the nutritional status of women and children by providing an integrated package of services to the beneficiaries.

ICDS programme was conceived in Kerala since 1975 with an integrated delivery package of early child-hood services so that their synergistic effect can be taken full advantage of the scheme. The scheme targets the most vulnerable group of population including children up to 6 years of age, pregnant women and nursing mothers belonging to poor families and living in disadvantaged areas including backward rural areas, tribal areas and urban slums. The identification of beneficiaries is done through surveying the community and identifying the families living below the poverty line.

\section{Objectives and feature of ICDS}

The main objectives of ICDS include

1. To improve the nutritional and health status of children in the age of 0-6 years.

2. To lay the foundation for proper psychological, physical and social development of the child.

3. To reduce the incidence of mortality, morbidity, malnutrition and school drop-out.

4. To achieve effective coordination of policy and implementation amongst the various departments to promote child development.

5. To enhance the capability of the mother to look after the normal health and nutritional needs of the child through proper nutrition and health education.

\section{ICDS has some important and unique features which} include

1. It is a holistic approach for child development involving the active participation of mother.

2. It serves the extreme underprivileged communities of the backward and remote areas of the country. 
3. It delivers services at Anganwadi right at the doorsteps of the beneficiaries to ensure their maximum participation.

4. It comprises three essential components, which are nutrition, primary health care and education, delivered as a composite package of services to children and mothers.

5. It utilizes local women as honorary village level workers for the delivery of the package of services.

6. It works through a team approach, and members of the team include administers, professionals in service departments, academicians and voluntary workers.

7. It has tried to promote the culture of voluntary work and output related honours for social work.

\section{Structure of ICDS}

Table 1: Shows the brief structure of ICDS.

\begin{tabular}{|l|l|l|}
\hline Category & Department & Designation \\
\hline State-level & $\begin{array}{l}\text { Directorate of } \\
\text { social welfare }\end{array}$ & Director \\
\hline level & $\begin{array}{l}\text { ICDS Project } \\
\text { office }\end{array}$ & $\begin{array}{l}\text { Child development } \\
\text { project officer }(1 / 5 \\
\text { supervisors) }\end{array}$ \\
\hline $\begin{array}{l}\text { Project- } \\
\text { level }\end{array}$ & $\begin{array}{l}\text { ICDS Project } \\
\text { office }\end{array}$ & $\begin{array}{l}\text { Supervisors (1/5 } \\
\text { AWS) }\end{array}$ \\
\hline Unit-level & $\begin{array}{l}\text { Anganwadi } \\
\text { centre }\end{array}$ & $\begin{array}{l}\text { Anganwadi workers } \\
\text { (teacher) } \\
\text { Anganwadi helper }\end{array}$ \\
\hline \multicolumn{2}{|l|}{ Source: Official website of Govt. of Kerala } \\
\hline
\end{tabular}

Participation of local community is considered an essential pre-requisite for the effective implementation of ICDS scheme. For this purpose, it has been stipulated that the Anganwadi worker (teacher) attached to a centre should be a resident of the beneficiary area of that centre. It is also envisaged that a local people's committee should be constituted for the smooth functioning of each centre with people's representative of the panchayath ward as its chairperson.

\section{Service provided through ICDS}

The main objectives achieved through a package of services comprising

1. Supplementary nutrition.

2. Immunization.

3. Health checkup.

4. Referral services.

5. Pre-school non-formal education and nutrition and health education.

The concept of providing a package of services (Table 2) is based primarily on the consideration that the overall impact will be much larger if the different service develop in an integrated manner as the efficacy of a particular service depends on the support it receive from related services.
Table 2: Service provided by ICDS in Kerala

\begin{tabular}{|c|c|c|}
\hline Service & Target Group & $\begin{array}{l}\text { Service } \\
\text { Providing Wing }\end{array}$ \\
\hline $\begin{array}{l}\text { Supplementary } \\
\text { nutrition }\end{array}$ & $\begin{array}{l}\text { Children below } \\
6 \text { years, } \\
\text { pregnant and } \\
\text { lactating } \\
\text { mothers }\end{array}$ & $\begin{array}{l}\text { Anganwadi } \\
\text { worker and } \\
\text { Anganwadi } \\
\text { helper }\end{array}$ \\
\hline Immunization & $\begin{array}{l}\text { Children below } \\
6 \text { years, } \\
\text { pregnant and } \\
\text { lactating mother }\end{array}$ & ANM/AWW \\
\hline $\begin{array}{l}\text { Health check- } \\
\text { up }\end{array}$ & $\begin{array}{l}\text { Children below } \\
6 \text { years, } \\
\text { pregnant and } \\
\text { lactating } \\
\text { mothers }\end{array}$ & ANM/MO/AWW \\
\hline $\begin{array}{l}\text { Referral } \\
\text { services }\end{array}$ & $\begin{array}{l}\text { Children below } \\
6 \text { years, } \\
\text { pregnant and } \\
\text { lactating } \\
\text { mothers }\end{array}$ & AWW/ANM/MO \\
\hline $\begin{array}{l}\text { Pre-school } \\
\text { education }\end{array}$ & $\begin{array}{l}\text { Children: 3-6 } \\
\text { years }\end{array}$ & AWW \\
\hline $\begin{array}{l}\text { Nutrition and } \\
\text { health } \\
\text { education }\end{array}$ & $\begin{array}{l}\text { Women: } 15-45 \\
\text { years }\end{array}$ & AWW/ANM/MO \\
\hline
\end{tabular}

\section{Nutrition status of children}

Malnutrition is a biggest health problem and the economic condition of a vast majority of population is so poor that they are not in a position to afford even the least expensive balanced diets. Children and women in the productive period appear to be the worst suffer. Several aspects related to the decline in under nutrition have been examined. It has been noted that young children belonging to special groups, namely, scheduled castes, scheduled tribes and backward communities, had all shown beneficial impact of ICDS on their nutritional status.

A decade after ICDS was instituted; evaluation studies suggested that the decline in infant and early childhood mortality rates, observed in areas where ICDS was operational, was significantly greater than the decline reported in the national data of the sample registration scheme. Recent data confirmed these earlier findings and show lower neonatal, infant and early childhood mortality rates in ICDS covered populations as compared to the overall national data (Karunakaran N, 2016). Table 3 shows that majority of mothers are general category and are educated and included in the age group 31 to 40.57 percent mothers have perfect knowledge about malnutrition and 35 percent have average knowledge. 83 percent support diseases and infections are main reasons for the weak health of children. Similarly poverty and poor hygiene also affect the health of children. 
Table 3: Reason for Malnutrition of Children in the study area (in percentage)

\begin{tabular}{|c|c|c|c|c|c|c|}
\hline \multirow{2}{*}{\multicolumn{2}{|c|}{$\begin{array}{l}\text { Category } \\
\text { Mothers of different aged } \\
\text { Children }\end{array}$}} & \multicolumn{4}{|c|}{ Year } & \multirow{3}{*}{$\begin{array}{l}\text { Total } \\
57\end{array}$} \\
\hline & & \multirow{2}{*}{\begin{tabular}{|l|}
3 \\
22
\end{tabular}} & \multirow{2}{*}{\begin{tabular}{|l|}
4 \\
13
\end{tabular}} & \multirow{2}{*}{$\frac{5}{15}$} & \multirow{2}{*}{$\begin{array}{l}6 \\
7\end{array}$} & \\
\hline \multirow{3}{*}{ Caste } & General & & & & & \\
\hline & OBC & 10 & 7 & 5 & 1 & 23 \\
\hline & ST & 7 & 7 & 5 & 1 & 20 \\
\hline \multirow[t]{3}{*}{ Education } & $\begin{array}{l}\text { First } \\
\text { school } \\
\text { leaving } \\
\text { certificate }\end{array}$ & 3 & 2 & 2 & 2 & 9 \\
\hline & $\begin{array}{l}\text { Ordinary } \\
\text { level }\end{array}$ & 12 & 5 & 5 & 2 & 24 \\
\hline & Advanced & 22 & 23 & 17 & 5 & 67 \\
\hline \multirow{3}{*}{ Age in year } & $21-30$ & 13 & 13 & 12 & 5 & 43 \\
\hline & $31-40$ & 20 & 13 & 12 & 4 & 49 \\
\hline & Above 40 & 5 & 1 & 1 & 1 & 8 \\
\hline \multirow{3}{*}{$\begin{array}{l}\text { Mothers } \\
\text { knowledge } \\
\text { about } \\
\text { malnutrition }\end{array}$} & Poor & 5 & 1 & 1 & 1 & 8 \\
\hline & Average & 12 & 11 & 11 & 1 & 35 \\
\hline & Better & 20 & 15 & 15 & 7 & 57 \\
\hline \multirow{3}{*}{$\begin{array}{l}\text { Causes for } \\
\text { malnutrition }\end{array}$} & $\begin{array}{l}\text { Poor } \\
\text { hygiene }\end{array}$ & 4 & 1 & 1 & 1 & 7 \\
\hline & Poverty & 4 & 2 & 2 & 2 & 10 \\
\hline & $\begin{array}{l}\text { Diseases } \\
\text { and } \\
\text { infection }\end{array}$ & 30 & 22 & 23 & 8 & 83 \\
\hline
\end{tabular}

\section{Conclusion}

In Kerala, ICDS are functioning with more than 15000 Anganwadi center in 150 and more blocks. This scheme was organized to bring about the overall development focusing on the physical, psycho-social and cognitive aspect. It is observed that child will reach its full potential through integrated approaches and calls for care and nutrition of adolescent, women and children through focused, child centered approach requiring inter-sectoral linkages and convergence of service. Through Supplementary Nutrition
Programme, highly nutritious food to children is provided, in addition to health education of mothers. Poverty, diseases, infection, lack of knowledge of parents, and also the health of mother are still adversely affecting the effectiveness of this scheme.

\section{Source of Funding}

None.

\section{Conflict of Interest}

None.

\section{References}

1. Karunakaran N. "An Overview of Integrated Child Development Scheme (ICDS) on the Nutritional Status of Children in the Rural Areas of Kerala", Rural Development in India: Policies and Programmes (Ed), Edited by Abdul Azeez NP and S. M. Jawed Akhtar, Gyan Books, New Delhi, India. 2016; 341-52.

2. Kristine Peterson. "Childhood under-nutrition: a falling global priority”, J Public Health Policy. 2009;30(4):455-64.

3. Gragnolati M, Caryn, Gupta MD. "ICDS and persistent undernutrition: strategies to enhance the impact", Econ Political Weekly. (2006);41(12):1193-201.

4. Mushtaq PMA, Fatima A, DK Veeresappa, Prasad RV. “A socio-demographic study on prevalence of under nutrition preschool children under rural area of Anthrapradesh", Int $j$ Community Med Public Health. 2017;4(1):16-28.

5. Nair KRG. Malnourishment among child in India: a regional analysis", Econ Political Weekly. 2007;42(37):3797-803.

6. Nandini Nayak and Naresh C Saxeena. "Implementation of ICDS in Bihar and Jharkhand", Econ Political Weekly. 2006;41(34):3680-84.

7. Samir Garg. "Grass root mobilization for children's nutrition rights”, Econ Political Weekly. (2006),41(34):3694-700.

8. Mehrotra S, Child malnutrition and gender discrimination in south Asia", Econ Political Weekly. 2006;41(10):912-18.

9. Shanti Ghosh. "Child malnutrition", Econ Political Weekly. 2004;39(40):4412-13.

How to cite: Karunakaran N. ICDS and Supplementary Nutrition Programme to children in rural areas of Kasargod, Kerala. J Manag Res Anal. 2020;7(3):111-3. 